\title{
Strong historical and ongoing indigenous marine governance in the northeast Pacific Ocean: a case study of the Kitasoo/Xai'xais First Nation
}

\author{
Natalie Ban $^{1}$, Emma Wilson ${ }^{1,2}$ and Doug Neasloss ${ }^{2}$
}

\begin{abstract}
Indigenous marine governance is increasingly recognized as having a crucial role in marine management and conservation, yet most examples are from the tropical Pacific and Oceania. We showcase strong and ongoing marine governance by the Kitasoo/ Xai'xais people of British Columbia, Canada. In partnership with the Kitasoo/Xai'xais Stewardship Authority, we synthesized information about marine governance by the Kitasoo/Xai'xais people as collated in their Heritage Database, a compilation of interviews and recordings with knowledge holders, traditional stories, and historical documents, e.g., journals of explorers and anthropologists. We found that Kitasoo/Xai'xais marine governance underpinned sustainable resource use and has remained strong despite colonial efforts to undermine it. Kitasoo/Xai'xais marine governance flows from the underlying principles of their indigenous law that guide all actions in the traditional territory. The social institutions of the Kitasoo/Xai'xais people are the mechanism for implementing marine governance: Importantly, hereditary chiefs hold key responsibilities regarding management of the oceans, embedded in ownership of specific places, passed on through names and stories. Kitasoo/Xai'xais protocols exist for respecting their territories, those of other nations, and the plants and animals being harvested. There are natural and spiritual consequences for not accessing and sharing marine resources in a way that follows Kitasoo/Xai'xais underlying principles, including loss of access. Contemporary examples of marine governance include the work of Kitasoo/Xai'xais Stewardship Authority, the Food Fish Committee guided by hereditary chiefs and elders, and everyone's actions to defend their territory from external threats. Given global efforts to recognize indigenous rights, an opportunity exists to change ocean management to fully recognize indigenous marine governance and leadership.
\end{abstract}

Key Words: Community-based conservation; indigenous peoples; marine conservation; marine governance; marine tenures; northeast Pacific Ocean; Pacific Northwest; stewardship

\section{INTRODUCTION}

Improving governance of the oceans to counteract increasing threats and declining biodiversity is a global priority (Worm et al. 2006, Johnson et al. 2017). Environmental governance, broadly encompassing ocean, marine, and fisheries governance, refers to the values, norms, and processes that shape the use of natural resources and control their exploitation or support protection (Richardson 2008). Institutions are the structures or mechanisms that stipulate the behavior of people (Chuenpagdee and Song 2012). Reducing declines of marine biodiversity requires governance and legitimate institutions (Young et al. 2007, Chuenpagdee and Song 2012) that are adaptive to changes in environmental and social conditions (Armitage et al. 2009). Reducing marine biodiversity declines can be especially challenging for common pool resources such as fisheries (Ostrom 1990).

Governance by indigenous peoples of their land and sea territories has been recognized by international bodies as an important avenue for achieving sustainable use and conservation while upholding indigenous rights (World Commission on Environment and Development 1987, Office of the High Commissioner for Human Rights 2008). Indeed, in some parts of the world, especially Oceania, indigenous marine governance systems have been embraced and revitalized and are forming the basis of contemporary ocean management (Johannes 2002, Cinner and Aswani 2007, Jupiter et al. 2014). In particular, customary marine tenure, often in the form of locally managed marine areas, includes common forms of local adaptations to manage marine species and spaces (Lam 1998, Cinner 2005, Cinner et al. 2007). In other regions, especially where colonial forces actively undermine or have undermined indigenous peoples, indigenous governance revitalizations efforts are underway, but recognition by colonial governments is slow (Bess 2001, Nursey-Bray and Rist 2009, Nursey-Bray and Jacobson 2014, Ban and Frid 2018, Eckert et al. 2018).

Indigenous marine governance institutions have received the most research attention in places where such institutions are clearly active and recognized (Johannes 2002, Cinner and Aswani 2007) but have garnered much less attention elsewhere. However, indigenous ocean governance and associated institutions provide opportunities to improve fisheries and oceans governance (Ban and Frid 2018), while also revitalizing and reinvigorating such practices to support indigenous cultural resurgence (Office of the High Commissioner for Human Rights 2008, Ban and Frid 2018). Indeed, in places where indigenous peoples reside by the ocean, marine governance has existed and may continue in ways unrecognized by colonial governments. Enabling indigenous governance to take a leading role in managing the oceans involves, as a first step, documenting the marine governance processes and protocols of indigenous peoples.

One region where indigenous ocean governance is receiving research attention but not yet substantial national or international recognition is the northeast Pacific (also known as the Northwest Pacific Coast of North America). The long-term marine stewardship of indigenous peoples has been documented in this region (Trosper 2003, 2009), for example, through traditional management systems including harvesting methods, enhancement strategies, tenure systems, and worldview and social relations (Lepofsky and Caldwell 2013). Accounts of specific species or 
suites of species illustrate seascape-scale mariculture, commonly called "clam gardens" (Groesbeck et al. 2014, Deur et al. 2015), and deliberate past and ongoing management and cultivation of, for instance, herring (Clupea pallasii; Thornton and Hebert 2015), salmon (Oncorhynchus spp.; Thornton et al. 2015), and crabs (Cancer magister; Ban et al. 2017). A strong conservation ethic permeates indigenous stewardship in the northeast Pacific, originating either through incremental learning (Turner and Berkes 2006) or as a response to past crises (Berkes and Turner 2006). However, colonialism deliberately undermined indigenous governance, and indigenous authority remains under-recognized (Truth and Reconciliation Commission 2015).

The purpose of this research was to showcase a case study in the northeast Pacific Ocean (British Columbia, Canada) where indigenous peoples have strong and ongoing involvement in marine governance. We partnered with the Kitasoo/Xai'xais First Nation in their efforts to document their marine governance and institutions. Our objectives were to synthesize Kitasoo/Xai'xais marine governance processes and protocols and illustrate contemporary applications thereof. We explored the underlying principles and governance processes that guide Kitasoo/Xai'xais marine governance and that could be used in marine management going forward, such as tribal parks, marine spatial planning, marine protected areas (MPAs), indigenous protected areas, and fisheries management. We focused on marine governance because the Canadian governance and management approach considers the marine environment separately from land and freshwater ecosystems. Kitasoo/Xai'xais governance systems do not make this distinction but rather see the ocean, land, and freshwater as a continuum. Still, for the sake of informing contemporary management, Kitasoo/Xai'xais considered it beneficial to synthesize their governance as it pertains to the marine environment. Kitasoo/Xai'xais partners were interested in showcasing their marine governance so that their desire for regaining authority to manage marine ecosystems and species in their territory may be recognized. Highlighting this case study of indigenous marine governance emphasizes the adaptive and ongoing nature of indigenous governance and underscores the important role of indigenous peoples in the future of the oceans.

\section{METHODS}

\section{Kitasoo/Xai'xais case study}

Since time immemorial, the lands and waters of what is now known as the central coast of British Columbia have been stewarded and protected by First Nation peoples. Two of these groups are the neighboring Kitasoo and Xai'xais (Fig. 1). The Kitasoo are a Tsimshian subgroup who lived in the western portion of the traditional territory and spoke Sguuks, the southernmost dialect of SmalygaxI (Kitasoo/Xai'xais First Nation 2011). The Xai'xais are a North Wakashan-speaking group that lived in the eastern portion in the inlets. The Kitasoo and Xai'xais had seasonal villages and harvesting sites spread throughout their territories (Kitasoo/Xai'xais First Nation 2011), and marine resources have always been central to both Kitasoo and Xai'xais livelihoods. Following substantial depopulation from epidemics, the two nations joined together in łmidu (Klemtu) in the 1870s and are now known as the Kitasoo/Xai'xais people (Kitasoo/Xai'xais First Nation 2011).
Fig. 1. Location of the Kitasoo/Xai'xais study area. The hatched area is the territory claimed by the Kitasoo/Xai'xais Nation.

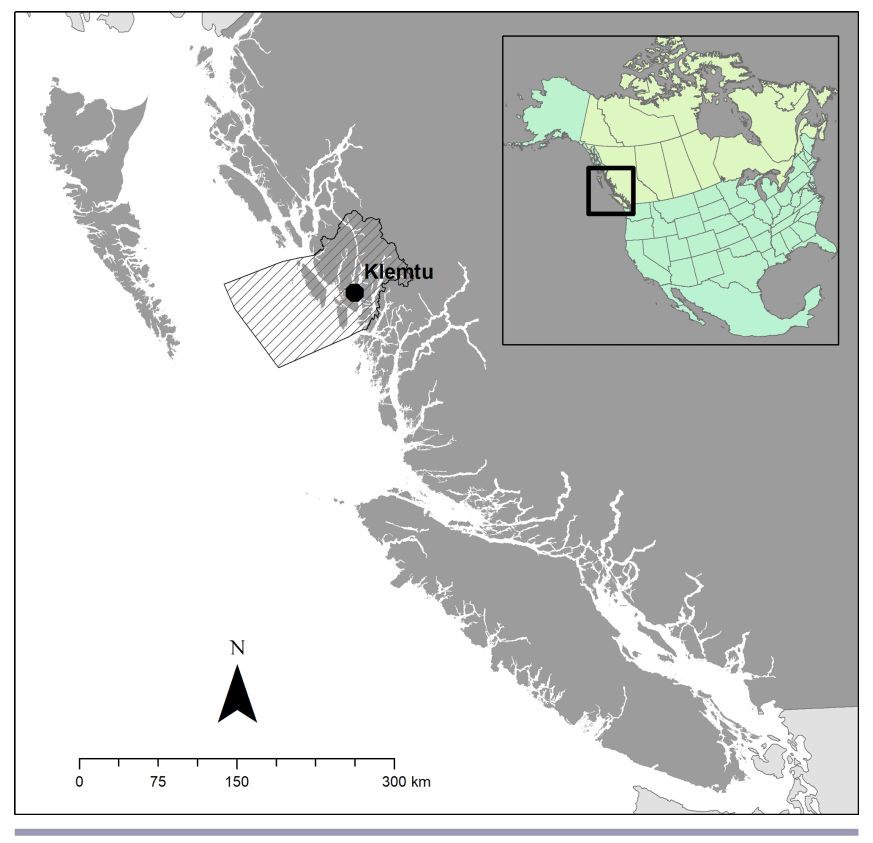

In 1867, the Canada Constitution Act assigned the federal government to hold exclusive legislative jurisdiction over First Nations and their territories. Following the Kitasoo/Xai'xais amalgamation, the Indian Act was passed in 1876 and specified how the federal government would manage "Indian" reserve lands. First Nation peoples were restricted to limited Indian reserves designated by the Indian agent of the time. Furthermore, European colonization of coastal regions resulted in rapid changes in indigenous management practices and declines in abundances of marine species following commercialization of resources (Harris 2001, Ommer 2007). The Indian Act and associated policies prohibited First Nations' cultural practices such as potlatches, i.e., gift-giving feasts, a crucial governance mechanism; banned indigenous selective fishing methods such as fish traps and weirs, now considered among the most sustainable fishing methods (Atlas et al. 2017); and forcibly removed children from their families, culture, and language by sending them to residential schools (Harris 2002, Regan 2010, Truth and Reconciliation Commission 2015). These policies severely diminished the well-being of First Nations, disrupting indigenous knowledge and management practices (Regan 2010, Truth and Reconciliation Commission 2015).

\section{Information and analyses}

The Kitasoo/Xai'xais First Nation has developed a program to document their indigenous laws, governance, practices, stories, and other culturally relevant items, called the Cultural Heritage Project. The aim of the Cultural Heritage Project is to reinvigorate, and reconstruct where necessary, Kitasoo/Xai'xais governance. Oral history passed down from generation to generation forms the core of the Cultural Heritage Project. Starting in 2014, staff of the Kitasoo/Xai'xais Stewardship 
Authority compiled and carefully documented transcripts from interviews with Kitasoo/Xai'xais elders and knowledge holders carried out by various people and projects over the years and archived on tapes in Kitasoo/Xai'xais offices. These interviews were transcribed and then supplemented by historical accounts of Kitasoo/Xai'xais practices and culture, obtained through archival research within the Kitasoo/Xai'xais offices and in regional, national, and international archives such as the British Columbia Archives, the Library and Archives Canada, and the American Philosophical Society, e.g., field notes of early explorers and documentation by anthropologists. The Kitasoo/Xai'xais stewardship team conducted additional interviews with elders to document their memories of indigenous laws and governance practices. Furthermore, the Kitasoo/Xai'xais researchers used a methodology developed by Friedland and Napoleon (2015) to derive Kitasoo/Xai'xais legal principles from the material, including Kitasoo/Xai'xais stories. Kitasoo/Xai'xais stories embody governance processes, principles, and practices and are important for teaching and maintaining governance. The work on deriving Kitasoo/Xai'xais legal principles and practices was done by and for the Kitasoo/Xai'xais First Nation and, as such, is separate from the research we present. All information is stored in the Kitasoo/Xai'xais Heritage Database, a living database that is updated by the Kitasoo/Xai'xais Stewardship Authority as new information becomes available.

We accessed and synthesized the sources in the Kitasoo/Xai'xais Heritage Database that mentioned the oceans and its inhabitants. This involved a careful review of all 2000 sources (as of February 2018) in the database by coding and summarizing relevant entries. More than 100 entries in the database were directly relevant to marine governance, including the following: transcripts of 59 interviews or statements (e.g., Enbridge pipeline hearings), from 1988 to 2017, 6 of which we carried out and added to the database; 19 Kitasoo/Xai'xais stories, 5 with case briefs; 17 historical documents; and 7 reports by the Kitasoo/Xai'sais Nation. The Kitasoo/Xai'xais Nation considers the details of the entries in its database to be confidential because the nation is using them to inform treaty discussions and other legal proceedings. To analyze the relevant entries in the database and organize the information, we adapted and simplified the framework developed by Friedland and Napoleon (2015) and the University of Victoria's Indigenous Law Research Unit (ILRU) for environmental issues (ILRU 2010). The analytical framework provides guiding questions to summarize and analyze governance principles and processes (Fig. 2). The marine governance principles and processes we summarize are different but complementary to the legal principles developed by the Kitasoo/Xai'xais First Nation. The framework guided organization of information about the following: importance of the ocean and relationships to it; marine governance and harvesting protocols and processes ("governance processes" in Fig. 2); marine relations with other nations ("other groups" in Fig. 2); consequences for not following protocols and practices; enforcement; and teachings. We used these headings to organize the Results. We also carried out six additional interviews with elders to fill gaps about information relating to the marine environment specifically (University of Victoria Ethic Protocol \#17-211). Transcriptions of these interviews are now included in the database.
Fig. 2. The analytical framework used to synthesize Kitasoo/ Xai'xais marine governance principles and protocols. The framework was adapted from the Indigenous Law Research Unit (2010) but was simplified and made specific to the ocean and its inhabitants. The foundational principles underpin all the other components. The ovals depict the guiding questions for components of governance related to people's relationship to the ocean, to the community, and to other groups, which all link to the governance processes. The boxes provide questions that are important for all the components, regarding teaching, consequences, and enforcement of governance processes.

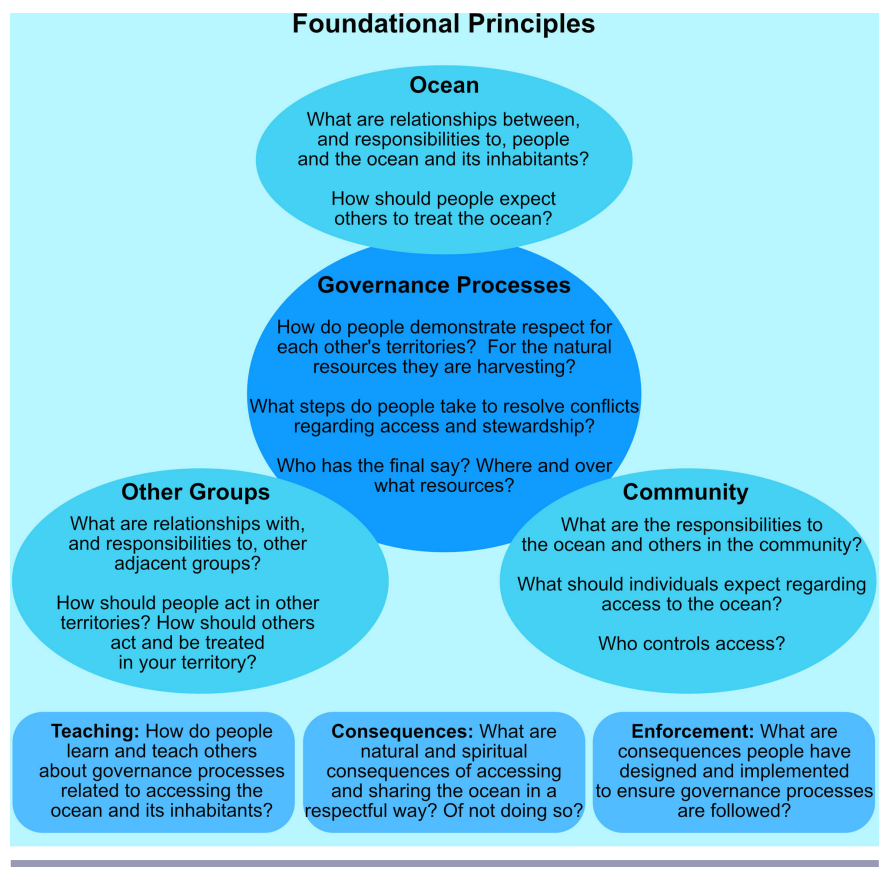

We summarized the Kitasoo/Xai'xais marine governance principles and processes into a detailed and carefully referenced confidential report for the Kitasoo/Xai'xais Nation. The Kitasoo/Xai'xais Heritage Database is an impressive compilation of Kitasoo/ Xai'xais culture, yet because of the direct efforts by the government to undermine indigenous languages, laws, and cultures during the colonization process, the database is incomplete. Our analysis thus focuses on documented knowledge about Kitasoo/Xai'xais marine governance but recognizes that this knowledge is not comprehensive and that gaps remain. We used a participatory process to develop and receive feedback on the Kitasoo/Xai'xais marine governance report. In fall 2017, we circulated a draft of the report for review by staff of the Kitasoo/Xai'xais Stewardship Authority and the Kitasoo/Xai'xais marine committee, composed of key Kitasoo/ Xai'xais elders and knowledge holders. We integrated suggestions and additional information uncovered through the review process into a revised draft. In February 2018, we hosted a community meeting to showcase the marine governance report and to receive additional feedback. The report was then finalized as a working version, which we anticipate will be updated in the future as additional information is uncovered. 
Table 1. General Kitasoo/Xai'xais legal principles.

\begin{tabular}{ll}
\hline \hline Legal Principle & Definition \\
\hline Respect & Everything has the right to be respected in all forms, including physically and verbally. Respect extends beyond \\
& people, to include animals and plants of the ocean and land. \\
Reciprocity & Everyone has a responsibility to show gratitude and maintain reciprocity in relationships with the land, sea, \\
& natural environment, and humans. \\
Intergenerational knowledge & People should base decisions on learning from experience, drawing on intergenerational knowledge, through which \\
& past experiences are passed down. It is the responsibility of community members and elders to teach younger \\
& generations their knowledge. \\
Interconnectedness & Everyone has a responsibility to ensure intergenerational equity by using resources sustainably, practicing \\
& integrated management, and distributing costs and benefits fairly between current and future generations.
\end{tabular}

We summarize the Kitasoo/Xai'xais marine governance protocols and processes, synthesizing information from the confidential report. We thus provide an overview of Kitasoo/Xai'xais marine governance, without disclosing confidential information about specific places, stories, or sources.

\section{RESULTS}

Overview: importance of the oceans and key concepts in Kitasoo/ Xai'xais marine governance

The Kitasoo/Xai'xais people have always governed their ocean and marine resources and continue to maintain and protect them, considering the ocean sacred in its entirety. The importance of the ocean is reflected in some of their names: Examples of hereditary chief names include Wudimas (stringy red seaweed that grows on rocks) and Dsagmsagisk (dragging along the shore/to pull as an anchor), and an example of a boy's name is Gwisdaayts (garment of seaweed or wearing a coat of seaweed). Kitasoo/ Xai'xais marine governance flows from the underlying principles of Kitasoo/Xai'xais law that guide all actions in the traditional territory: respect, reciprocity, intergenerational knowledge, and interconnectedness (Table 1). Everything, including people, plants, and animals, has the right to be respected in all forms, including physically and verbally. People have a responsibility to show gratitude and maintain reciprocity in relationships with the land, sea, natural environment, and humans. This responsibility is commonly shown through territorial access and gift giving. Exchanges can be between people, animals, and supernatural beings. People should base decisions on learning from experience, including the experiences of past generations. Exchanging intergenerational knowledge, especially through stories, is the main method to pass down past experiences. Story telling often occurs on the land and water while harvesting and processing foods, allowing informal learning to take place. Adaptive management is a scientific principle that ties in with this concept of "listening to your elders." Indeed, it is the responsibility of community members and elders to teach the younger generation their knowledge. Furthermore, the natural environment and its species, including humans, are all connected. This oneness means that one small change can affect everything else. Thus, everyone has a responsibility to ensure intergenerational and interspecies equity by using resources sustainably. Kitasoo/Xai'xais marine governance implements these underlying principles through societal structures and practices. The ocean is a key place where knowledge is passed through generations and teaching is performed.

\section{Kitasoo/Xai'xais marine governance institutions}

The social institutions of the Kitasoo/Xai'xais people form the basis of Kitasoo/Xai'xais marine governance: hereditary chiefs hold key responsibilities regarding management of the oceans, embedded in ownership of specific places, passed on through names and stories. Hereditary chiefs have the responsibility to look after their clan and to manage areas of land and sea held under their chief name. It is their responsibility to ensure the areas remain plentiful and healthy, which includes making decisions concerning harvesting, i.e., telling people when there are fish that can be harvested without depleting the stock. As an anonymous source states: "We respect our Chiefs. They're the ones that tell us when you guys got enough; leave it alone now, there's next year. We're always looking forward to the next year; like I said, we never, ever over-fished." People share, but people have to ask permission to use the area associated with a family. One reason to ask permission is because families or clans have traditionally "looked after their resources [and made] sure things were not abused" (Anonymous 1, July 2017). Historically, continued use of resources was a way of maintaining and displaying rights to areas and resources; it also served as a way of maintaining knowledge of baseline health of a resource and ensuring sustainable use.

Associated with hereditary chief names are territorial rights and stewardship responsibilities of looking after the clan and territory and hence ensuring active stewardship of marine areas. Hereditary chief names are passed on and are to stay within the community. As a source explains,

It is our custom that Chief's names have to stay in the village. If you move away, you can't take the name with you, you have to put up a feast and give the name back to your clan. This is very important. One of the reasons that a Chief's name must stay in the village is that it carries a responsibility to look after your clan, and to look after the places... You have to stay here to keep the name, you have to use it here because those with the big names have a responsibility to stay here and help out your clan and look after the land. I have always known it to be that way.

Because of the important responsibilities that come along with holding a hereditary chief name, it is fairly common for community members to turn down chief names if they do not feel that they are able to hold the office well. Hereditary chief names, and other names, are passed on during potlatches or feasts. A responsibility of hereditary chiefs is to know the area and the 
stories that originate there. Before a hereditary chief can claim a territory, he must "walk all the mountains, all the salmon streams to see what is there" (Anonymous 2, July 2017). Every mountain, river, lake, bay, and fishing spot has a name within the territory, and this is "passed on by Hereditary Chiefs to generation after generation" (Anonymous 3, April 1996). Traditional regalia reinforce stories. For instance, each traditional headpiece pays tribute to a story.

Clans own crests, names, and privileges of personal names, house names, canoe names, songs, and dances. There is a deep connection between clan animals and clan members embedded in respect. Clan animals, such as the killer whale, raven, wolf, and bald eagle, are known to look after their clan members. Names within oral history reinforce the Kitasoo/Xai'xais people's connection and ownership of the territory and the marine environment within it.

High-ranking ladies have an important role to assure marine governance is being adhered to by everyone, including hereditary chiefs. Historically, high-ranking ladies would overthrow hereditary chiefs who did not follow Kitasoo/Xai'xais underlying principles and harvesting protocols. A high-ranking lady name is bestowed on a woman to give her authority to stand up and help the community. Acting as the leader for fish preparation, highranking ladies "order different people around to do different things [during the process of] jar[ing] fish" (Anonymous 4, July 2017), in turn passing on their knowledge to others. They also are the ones "pushing ... help[ing] you to set things in order. They have their roles in governance of community" (Anonymous 4, July 2017). Another description is that the role of high-ranking ladies is to "tell the others what to do - what they're supposed to do and what they're not supposed to do" (Anonymous 5, January 2018).

Elders are highly respected and recognized as "judge and jury" among the Kitasoo/Xai' xais people. Their opinions and input are obtained by hereditary chiefs and high-ranking ladies on a wide variety of issues, including territorial encroachments and harvesting protocol abuses. As trusted community members, people go to elders to disclose information on abuses, such as someone fishing in a spot where he or she is not supposed to be. Elders hold an enormous amount of traditional knowledge and are key consultants for marine governance. For example, because elders know the history of names, they can assist with harvesting laws and dispute resolution in regard to land and sea ownership.

Marriages have been an important part of life to access, uphold, and share resources. Increasing access to resources and keeping resources within the community are two key reasons for marriages. Arranged marriages gave access for some time to family ties, family crests, and, therefore, family rights to territory. Sometimes marriages were arranged to keep resources within the community, thereby strengthening the Kitasoo/Xai'xais people. "You don't just marry anybody you want in those days, they had to keep their possessions within their family" (Anonymous 6, March 1994). Reinforcing access to resources still applies today to love marriages and happens through name giving to those who marry or their families.

Potlatches are a key governance institution. Marine territory rights are validated through potlatches that have been "established and formalized by means of demonstration of, and claims to, such rights through certain names, crests, and songs" (Anonymous 7, 1969). Potlatches give room for marriage ceremonies, name giving and solidification, and adoptions. In Xai'xais tradition, arranged marriage ceremonies were called Tuboats and were performed by a chief. It would be at this ceremony where the couple's future children would be named, "so they already had names, names were important those days, as a tag of whom you belong, crest, tribe, and where you can hunt, and where you can go" (Anonymous 8, May 1994). Names are given and solidified at potlatches so that people will remember and recognize them but also to prove that the future holder can uphold the name and the responsibilities associated with it. Guests at potlatches serve as witnesses to the events that occurred. Hosts of potlatches provide food and gifts for guests to honor guests' witnessing of events. Hereditary chiefs who manage their area well are able to sustain hosting more potlatches, i.e., they are able to provision food for many people, hence gaining prestige and reinforcing their territorial rights. Potlatches also emphasize the sharing culture: People who have more resources hold more feasts, providing a means of redistributing wealth.

A key place for marine and other governance was Disju. One person explains it this way:

That's where the people, the Chiefs, [including from other nations ] met twice a year to meet and work together how they can govern their land. That's what the place was used for. It's called Disju, people of Kitasoo. That's what it's called, Disju. That's where my people gathered every year. That's where the people met in the spring and in the fall, where they had to make sure that everything is run the way it should, the way the Chiefs wanted it to. That place is a very valuable place to us. That's where my ancestors lived before we were put in this reservation system.

In Kitasoo tradition, decision making included all "the leaders when they met in Disju - all the hereditary chiefs, elders, and matriarchs trying to solve the problems" (Anonymous 9, July 2016). Disju was used
for disputes, like if your family didn't get anything and you came into my area and you know, we' [d] almost have a big war over it, but the chiefs of the whole territory got called in: "This is the reason why we have this land. This is the reason you're responsible for your area ... if you don't look after yours and start cutting in to everybody else's ... it's quite possible that you might clean it all out so let's do things right and just work together" (Anonymous 9, July 2016).

Hereditary chiefs, high-ranking ladies, and elders are key decision makers who hold authority and roles in marine governance and management, and today the board of the Kitasoo/Xai'xais Stewardship Authority and the Kitasoo/Xai'xais Food Fish Committee, made up of hereditary chiefs and elders, also play a role. Developed by the hereditary chiefs to cope with the changes in marine resource stocks, the Food Fish Committee stipulates the amount, location, and timing in which community members can harvest. It also monitors community members' catches and closes and monitors areas when there is a conservation concern. Indeed, everyone assists with monitoring the conservation 
decisions by the Food Fish Committee. For example, there was an instance of an elder hunting deer in Kitasu Bay during herring spawning season, a prohibited activity. All fishers on the water that day went to "ream him out," or tell him that what he had done was wrong. In addition, elders, and later an elected council, are sought after for advice and consulted on issues relevant to marine governance and management. Community members also inform these authoritative decision makers.

Today, there are examples where Hereditary Chiefs continue to use their long-standing authority to stand against government pronouncements with which the community disagrees. When Fisheries and Oceans Canada disclosed new fishing regulations in Kitasu Bay for community members, the hereditary chiefs told the fisheries officer: "We do not accept this. We don't want it. We don't want to be told how much fish we should catch and how many pounds of herring roe we can put away." A hereditary chief said he told the other chiefs, "We're going out now, come on now." He says, "I called my people out: 'Let's go, let's go out to Kitasu Bay. It's time to go out.' We all went out." Through this act of self-determination, this hereditary chief and others practiced their authority in regard to harvesting decisions. Today, Kitasoo/ Xai'xais still assert the right to exclusive use of harvesting within the territory, although this is not currently recognized by the federal government. A hereditary chief makes it clear that the Kitasoo/Xai'xais continue to hold the right when he states, "It was not an entitlement, it was our right to fish." Kitasu Bay continues to be rich ecologically because the Kitasoo/Xai'xais have defended it from other uses for years. Another example is from the 1970s, when an area adjacent to Kitasu Bay was to be logged, which would have harmed herring populations. The government issued a permit for logging, and a logging road was built, but Kitasoo/Xai'xais protests prevented logging from taking place. In this way, the Kitasoo/Xai'xais continually demonstrate stewardship over their areas.

An example of ongoing and evolving Kitasoo/Xai'xais marine governance is their marine use plan. The Kitasoo/Xai'xais wrote a comprehensive marine use plan, developed over 5 years with more than 100 meetings per year and led by hereditary chiefs and elders. It is based on Kitasoo/Xai' xais indigenous laws, integrates science, involves capacity building, and focuses on economic development opportunities. It highlights important areas for conservation, food fishing, and other uses and has been used as the basis for Kitasoo/Xai'xais input into regional marine use plans.

\section{Marine resource harvesting protocols}

Kitasoo/Xai'xais protocols exist for respecting others' territories and the plants and animals being harvested. People demonstrate respect for each others' territories by asking permission and following the food fish rules, closures, and unwritten harvest principles, and they reciprocate by exchanging privileges to access territory. Kitasoo/Xai'xais marine resource harvesting protocols are embedded within Kitasoo/Xai'xais law (Table 1) and show the importance of harvesting, highlighting that it is an act to be undertaken with purpose and respect. Properly preparing for harvest materializes in various ways, happens on and off the water, involves showing respect for the resource being harvested. Proper preparation elongates the process of harvesting, giving the harvester an extended period for contemplation about what he or she harvests. A sense of respect and interconnectedness with what will be harvested is formed, thereby enhancing responsible and sustainable decision making. Observing purification rituals also allows the person to be undetected by animals and spirits in the marine environment. Examples include cleansing the stomach by drinking salt water in the morning, taking a bath to be clean before hunting, and cleaning/bathing with devil's club (Oplopanax horridus) before hunting or fishing to remove human odor. Offerings show respect for the species being harvested and for the environment. Similarly, when disposing of unusable waste from a harvest, it is required that people do so in a respectful manner by giving thanks. It is understood that if people do not respect these resources, they could easily be taken away.

While harvesting, it is required that people are aware and have knowledge of the surrounding environment. The intergenerational knowledge and connectedness principles (Table 1) require harvesters to follow the seasons and make decisions based on knowledge, not guesswork. Being aware of the surrounding environment is crucial so that people are not disruptive and can change actions accordingly around spawning and harvesting sites. An example is herring spawning sites, which can be disturbed quite easily.

Measures are taken to ensure protection and preservation of the marine environment. Particularly important is the responsibility to take only what is needed, not killing for fun, fully utilizing what is harvested, not overharvesting, and restoration. When animals are killed, there is an obligation not to waste anything, and hence every usable part of the animal is utilized. The marine environment is treated with respect: "I take what fish I need and then I quit" (Anonymous 10, 1988). The practice of renewing and restoring the environment has always been a part of Kitasoo/ Xai'xais harvesting protocols. For example, one individual remembers his grandfather talking about abalone (Haliotis kamtschatkana) being transplanted up and down a pass. Similarly, another recalls assisting in re-establishing the crab population in a bay.

Practices following a successful hunt or harvest ensure that the principles of reciprocity and sharing are upheld. For example, when a man catches his first fish, he is meant to distribute it to others. The act of sharing from your first harvest onward is to teach people that sharing is a responsibility throughout life. There is an obligation to share your harvest with others who are incapable of harvesting themselves.

The First Salmon Feast illustrates the Kitasoo/Xai'xais's relationship with the ocean: It is a celebration for the return of the salmon and happens in May. Before the amalgamation of Klemtu, the Xai'xais would bring eulachon (Thaleichthys pacificus) grease, and the Kitasoo would bring herring eggs. Coming together to feast on the first catch of sockeye salmon (Oncorhynchusnerka) gave the nations an opportunity to celebrate the return of the salmon, to talk about the importance of salmon, and to tell "The Big Salmon Story." When potlatches were banned, Kitasoo/Xai'xais still celebrated this important event but concealed it under the Salmon Queen and, later, the May Queen celebrations. A pole was erected next to the May Queen stand in the center of the community with "a salmon at the very top [signifying] the importance of salmon" (Anonymous 11, November 2017). People risked arrest to continue this important celebration. 


\section{Marine relations with other First Nations}

Relationships between neighboring First Nations and the Kitasoo/Xai'xais Nation have evolved over the years in regard to territories, alliances, and resource sharing. The Kitasoo/Xai'xais people uphold certain responsibilities to nations with overlapping and adjoining marine territories, including approaches to be followed to ensure respectful interaction while accessing resources within other nations' territories. To harvest resources in somebody else's territory, the protocol is to ask permission and communicate with whoever holds the area. Today, Kitasoo/Xai'xais show respect by calling ahead and letting neighbors know they would like to come, asking permission, and asking when is a good time. Sharing of resources and trade has always been a central part of Kitasoo/Xai'xais livelihood and stretches up and down the coast. If someone gives access to their area, people are expected to reciprocate the favor. Kitasoo/Xai'xais people require community members to uphold respectful relations with other nations when accessing resources within their territory. Although sharing is common, the Kitasoo/Xai'xais have the right to exclude people and regulate access to the territory. It is considered a privilege, and not a right, for other territorial groups to access and harvest on Kitasoo/Xai'xais territory (and vice versa). When there was an abundance of natural resources, there was no cause for concern about allowing neighboring groups to share in the wealth of Kitasoo/Xai'xais territory. There are historic intertribal agreements with neighbors about uses and boundaries that are based on respect and reciprocity.

\section{Consequences}

There are natural and spiritual consequences for not accessing and sharing marine resources in a way that follows Kitasoo/ Xai'xais underlying principles, protocols, and practices. The main consequence for acting irresponsibly and harvesting unsustainably is loss of access. However, punishment will be inflicted if people are not respectful toward all living things, whether or not they are being harvested. Overharvesting comes with consequences that affect environmental and community health. Consequences for disrespecting marine species are apparent within oral stories; indeed, a main role of stories is to teach about consequences so that protocols and practices are respected, and territories sustainably managed. Although retribution is common when wrongdoing occurs, people can also be forgiven or given a second chance in certain circumstances. Oral stories that involve the protagonist doing something wrong and being punished for that act often end in forgiveness.

\section{Enforcement}

Everyone plays a role in enforcement. For example, members of the community will tell chiefs or elders if they see someone fishing in a particular spot where he or she is not supposed to be. Hereditary chiefs and elected chiefs work with elders and resource stewardship to enforce contemporary harvesting laws. The Kitasoo/Xai'xais Coastal Guardian Watchmen monitor and protect the marine and terrestrial territory within Kitasoo/ Xai'xais territory. The watchmen ensure that anyone in Kitasoo/ Xai'xais territory acts responsibly.

\section{Teaching}

There are effective ways people learn and teach about Kitasoo/ Xai'xais protocols and the marine environment. Sharing oral history and modeling respect and reciprocity are the main avenues for the transmission of information. The principle of intergenerational knowledge relies on the transfer of knowledge between generations: Parents, grandparents, and elders have a responsibility to teach young people about the proper way to act. Indeed, a central part of teaching is through elders telling stories. Learning by doing is a theme seen throughout, and access to the marine territory to learn is important. Not only is oral history quite commonly related to marine resources, but the act of sharing happens frequently on the ocean. Traveling to and from various harvesting sites allows for intimate time with teachers and sparking memories of stories. It is everyone's responsibility to demonstrate the proper way to act.

Recording past events is an important aspect of oral history. Oral stories are a key component of oral histories, and the ocean is the setting of the majority of Kitasoo/Xai'xais stories. Stories have been recorded in various monuments to preserve their teachings. For example, a flagpole in Klemtu was erected to commemorate "The Big Salmon." It reminds people today of the story's teaching that there are serious consequences for those that try to take away or exercise powers to which they are not entitled. The design of Klemtu's big house contains many parts of "The Underwater Big House Story," illustrating the continuation of this tradition.

\section{DISCUSSION}

As part of the Kitasoo/Xai'xais Cultural Heritage Project, we synthesized marine governance processes and protocols. Unlike some nations where indigenous governance is recognized by nation-state governments, such as tropical Pacific island nations (Veitayaki et al. 2003, Jupiter et al. 2014), the Canadian government's colonial legacy actively undermined and criminalized indigenous governance and management (Truth and Reconciliation Commission 2015). However, through multiple lines of inquiry, including interviews, archival information, and stories, we were able to develop a first synthesis of past and contemporary Kitasoo/Xai'xais marine governance based on existing information. The resilience of indigenous marine governance is remarkable given the past criminalization and ongoing denial of indigenous authority (Lepofsky and Caldwell 2013, Truth and Reconciliation Commission 2015). The important role of hereditary chiefs, elders, high-ranking ladies, and institutions such as potlaches remain as relevant as ever. Indeed, the Kitasoo/Xai'xais have never stopped asserting their governance rights even though the federal government does not fully recognize those rights. Indeed, Kitasoo/Xai'xais marine governance showcases adaptive governance in action, defined as managing diverse human environmental interactions in the face of uncertainty (Dietz et al. 2003, Folke et al. 2005). By illustrating the ongoing and complex Kitasoo/Xai'xais marine governance processes and institutions, we suggest that the northeast Pacific Ocean should be added as a global example of a region with rich, complex, and ongoing indigenous marine governance.

The literature on common pool resources frames resource management as being composed of a range of property rights (Schlager and Ostrom 1992, Agrawal 2001), all of which are evident in our case study. In particular, the hereditary chief and related institutions can change access, withdrawal, management, and exclusion rights, and there are strict protocols around alienation rights. In addition to the property rights, a unique aspect of hereditary chief ownership is that it comes with a 
responsibility to steward the land and sea and to set a good example for the community. Furthermore, resource management can include various restrictions, all of which are used in Kitasoo/ Xai'xais marine governance: spatial, temporal, gear or harvesting technology, effort (e.g., number of participants), types of species that can be harvested, and quantity of resources harvested (Cinner and Aswani 2007). Kitasoo/Xai'xais marine governance processes and protocols go beyond the mere ability to regulate property rights and impose restrictions by incorporating all elements of marine governance into the Kitasoo/Xai'xais worldview and way of being and living. Other studies in the region have likewise noted the strong entwining of marine governance and worldviews (Turner and Berkes 2006, Lepofsky and Caldwell 2013, Groesbeck et al. 2014, Thornton et al. 2015).

Contrary to the suggestion in the literature on environmental governance that conservation and management regimes ought to be different for different species or resource units (Smith and Wishnie 2000, Hunn et al. 2003, Ostrom 2009), we found evidence that the Kitasoo/Xai'xais marine management regime is comprehensive for all resources found within an area. There are two possible explanations. First, given that hereditary chiefs have stewardship responsibilities over their chiefdom areas, the general approach for managing multiple resources might be consistent for all resources within a given area. Indeed, the spatial focus might be the anchor of the governance system, rather than the contemporary single-species fisheries management approach. Second, it may be possible that there was insufficient evidence in the Kitasoo/Xai'xais Heritage Database for us to be able to differentiate protocols and processes for individual species. We suspect the reality may be a combination of these two possibilities, namely, that there is a common approach for stewardship, but that the specific actions vary by species. For instance, case studies in the literature showcase specific stewardship actions for species by indigenous peoples in the Pacific Northwest of North America, such as the Huna Tlingit traditional gullegg harvest (Hunn et al. 2003) or herring management (Jones et al. 2017, Kitasoo/Xai'xais First Nation 2017).

Our synthesis of Kitasoo/Xai'xais marine governance includes many aspects of potential interest to scholars for future theorizing and for comparison with other governance systems. For example, as Trosper (2002) noted about Northwest Coast potlatches generally, the Kitasoo/Xai'xais potlaches likewise serve as a means of distributing rather than accumulating wealth. Hereditary chiefs gain status by holding these potlatch feasts, which requires feeding all who are invited with harvests from the territory of the host, thereby creating an incentive for sustainable fisheries management (Trosper 2002). However, this incentive that supports sustainability is rarely mentioned in the resource management literature about common pool resources. Similarly, hereditary chief names have to stay within the community, which ensures that chiefs are nearby their territories and people; they cannot continue in their role if they move to another nation's village. This is anoher way of ensuring active management. There are many other such themes of interest to scholars in our description of Kitasoo/Xai'xais marine governance.

Given that the Canadian federal government signed the United Nations Declaration for the Rights of Indigenous Peoples (Office of the High Commissioner for Human Rights 2008) and proclaims a commitment to reconciliation (Truth and Reconciliation Commission 2015), an opportunity exists to change ocean management to fully recognize indigenous marine governance and leadership. Some attempts are underway in British Columbia. The Marine Plan Partnership (MaPP; $\underline{\text { http:// }}$ mappocean.org/) is a co-led process between 17 First Nations and the government of British Columbia to develop and implement plans for marine uses on British Columbia's North Pacific Coast. Without involvement by the federal government, however, managing fisheries, marine transportation, and other uses under federal jurisdiction is currently beyond the scope of these plans. Management of some individual fisheries is starting to be done cooperatively with First Nations. For example, discussions are ongoing for comanagement of herring fisheries on the central coast of British Columbia, but it took years of protests by First Nations and development of their own herring management plans (e.g., Kitasoo/Xai'xais First Nation 2017) to reach the point of constructive discussions. Furthermore, an MPA planning process is underway, co-led by 17 First Nations, the government of Canada, and the province of British Columbia (http:// mpanetwork.ca/). Although MPAs have great promise for enabling indigenous governance approaches in specific areas (Ban and Frid 2018), fully recognizing indigenous authorities and institutions will require moving beyond MPAs and individual fisheries.

Approaches other countries have taken to recognize indigenous marine governance have varied. For example, the Palauan constitution grants a great deal of authority to customary law (Johannes 2002). In Fiji, customary marine tenure is formalized through the iqoliqoli system, delineated areas with customary fishing rights that are managed by chiefs (Sievanen et al. 2013, Jupiter et al. 2014). New Zealand has mätaitai reserves, important fishing grounds managed by Maori for customary purposes, and taiapure areas, which have special customary significance for the Maori and where they can restrict uses. Maori communities apply to the minister of fisheries to create these areas (Stephenson et al. 2014). In Samoa, villages have the ability to create and enforce village fisheries management plans (Fa'asili and Kelokolo 1999). In Chile, local fishing cooperatives manage their fisheries through territorial user rights (Gelcich et al. 2010). None of these systems are static, nor are they without problems (Johannes 2002), but they show that nation-states can and have embraced contextspecific indigenous marine governance or hybrid systems.

Our account of Kitasoo/Xai'xais marine governance has been limited by the information available. The colonial legacy of diseases, banning of cultural practices, residential schools, and so on (Truth and Reconciliation Commission 2015) has affected the continuity of knowledge. However, remarkably, much knowledge remains, and accounts from multiple knowledge holders and historical documents are consistent. Furthermore, governance processes and protocols are constantly adapting and evolving. Thus, our summary represents a snapshot in time given currently available information. It is not meant as a comprehensive synthesis, but rather as the beginning of the process of revitalizing and adapting Kitasoo/Xai'xais marine governance. Similarly, although enough information remains to start documenting Kitasoo/Xai'xais marine governance, we do not have information about the evolution of their governance system and are thus unable to comment on whether it evolved through incremental 
learning (Turner and Berkes 2006) or as reactions to past crises (Berkes and Turner 2006).

The research we did with the Kitasoo/Xai'xais First Nation provides only one example of the many coastal First Nations that have similarly rich histories of indigenous marine governance (e.g., Trosper 2003, 2009, Turner and Berkes 2006, Lepofsky and Caldwell 2013, Groesbeck et al. 2014, Thornton et al. 2015). We suggest that the assertion about rich customary management should be expanded to include the northeast Pacific Ocean, and not just Oceania. Just as Oceania was observed to have seen the demise (Johannes 1978) and subsequent renaissance of customary management (Johannes 2002), so too is the northeast Pacific Ocean currently undergoing that revitalization.

Responses to this article can be read online at: http://www.ecologyandsociety.org/issues/responses. php/11091

\begin{abstract}
Acknowledgments:
We are grateful to members of the Kitasoo/Xai'xais First Nation who generously shared their time and knowledge with us for this project. We thank all the Kitasoo/Xai'xais knowledge holders who contributed to the broader Heritage Project. We also thank the Kitasoo/Xai'xais leadership for supporting this project, Resource Stewardship past and present employees, and Sam Harrison for insightful comments and edits. We thank Cole McKnight for his research assistant support during the summer of 2017. Funding was provided by the Tides Canada Foundation-British Columbia Marine Planning Fund and the University of Victoria Lansdowne Award.
\end{abstract}

\section{LITERATURE CITED}

Agrawal, A. 2001. Common property institutions and sustainable governance of resources. World Development 29:1649-1672. https://doi.org/10.1016/S0305-750X(01)00063-8

Armitage, D. R., R. Plummer, F. Berkes, R. I. Arthur, A. T. Charles, I. J. Davidson-Hunt, A. P. Diduck, N. C. Doubleday, D. S. Johnson, M. Marschke, P. McConney, E. W. Pinkerton, and E. K. Wollenberg. 2009. Adaptive co-management for social-ecological complexity. Frontiers in Ecology and the Environment 7:95-102. https://doi.org/10.1890/070089

Atlas, W. I., W. G. Housty, A. Béliveau, B. DeRoy, G. Callegari, M. Reid, and J. W. Moore. 2017. Ancient fish weir technology for modern stewardship: lessons from community-based salmon monitoring. Ecosystem Health and Sustainability 3:1341284. https://doi.org/10.1080/20964129.2017.1341284

Ban, N. C., L. Eckert, M. McGreer, and A. Frid. 2017. Indigenous knowledge as data for modern fishery management: a case study of Dungeness crab in Pacific Canada. Ecosystem Health and Sustainability 3:1379887. https://doi. org/10.1080/20964129.2017.1379887

Ban, N. C., and A. Frid. 2018. Indigenous peoples' rights and marine protected areas. Marine Policy 87:180-185. https://doi. org/10.1016/j.marpol.2017.10.020
Berkes, F., and N. J. Turner. 2006. Knowledge, learning and the evolution of conservation practice for social-ecological system resilience. Human Ecology 34:479-494. https://doi.org/10.1007/ s10745-006-9008-2

Bess, R. 2001. New Zealand's indigenous people and their claims to fisheries resources. Marine Policy 25:23-32. https://doi. org/10.1016/S0308-597X(00)00032-4

Chuenpagdee, R., and A. M. Song. 2012. Institutional thinking in fisheries governance: broadening perspectives. Current Opinion in Environmental Sustainability 4:309-315. https://doi.org/10.1016/ j.cosust.2012.05.006

Cinner, J. 2005. Socioeconomic factors influencing customary marine tenure in the Indo-Pacific. Ecology and Society 10(1):36. https://doi.org/10.5751/ES-01364-100136

Cinner, J. E., and S. Aswani. 2007. Integrating customary management into marine conservation. Biological Conservation 140:201-216. https://doi.org/10.1016/j.biocon.2007.08.008

Cinner, J. E., S. G. Sutton, and T. G. Bond. 2007. Socioeconomic thresholds that affect use of customary fisheries management tools. Conservation Biology 21:1603-1611. https://doi.org/10.1111/ j.1523-1739.2007.00796.x

Deur, D., A. Dick, K. Recalma-Clutesi, and N. J. Turner. 2015. Kwakwaka'wakw "clam gardens." Human Ecology 43:201-212. https://doi.org/10.1007/s10745-015-9743-3

Dietz, T., E. Ostrom, and P. C. Stern. 2003. The struggle to govern the commons. Science 302:1907-1912. https://doi.org/10.1126/ $\underline{\text { science. } 1091015}$

Eckert, L. E., N. C. Ban, S.-C. Tallio, and N. Turner. 2018. Linking marine conservation and Indigenous cultural revitalization: First Nations free themselves from externally imposed socialecological traps. Ecology and Society 23(4):23. https://doi. org/10.5751/ES-10417-230423

Fa'asili, U., and I. Kelokolo. 1999. The use of village by-laws in marine conservation and fisheries management. SPC Traditional Marine Research Management and Knowledge Information Bulletin 11:7-10.

Folke, C., T. Hahn, P. Olsson, and J. Norberg. 2005. Adaptive governance of social-ecological systems. Annual Review of Environment and Resources 30:441-473. https://doi.org/10.1146/ annurev.energy.30.050504.144511

Friedland, H., and V. Napoleon. 2015. Gathering the threads: developing a methodology for researching and rebuilding indigenous legal traditions. Lakehead Law Journal 1:16-44.

Gelcich, S., T. P. Hughes, P. Olsson, C. Folke, O. Defeo, M. Fernández, S. Foale, L. H. Gunderson, C. Rodríguez-Sickert, M. Scheffer, R. S. Steneck, and J. C. Castilla. 2010. Navigating transformations in governance of Chilean marine coastal resources. Proceedings of the National Academy of Sciences of the United States of America 107:16794-16799. https://doi. org/10.1073/pnas. 1012021107

Groesbeck, A. S., K. Rowell, D. Lepofsky, and A. K. Salomon. 2014. Ancient clam gardens increased shellfish production: adaptive strategies from the past can inform food security today. PLoS ONE 9:e91235. https://doi.org/10.1371/journal.pone.0091235 
Harris, D. C. 2001. Fish, law, and colonialism: the legal capture of salmon in British Columbia. University of Toronto Press, Toronto, Ontario, Canada. https://doi.org/10.3138/9781442674912

Harris, C. 2002. Making native space: colonialism, resistance, and reserves in British Columbia. University of British Columbia Press, Vancouver, British Columbia, Canada.

Hunn, E. S., D. R. Johnson, P. N. Russell, and T. F. Thornton. 2003. Huna Tlingit traditional environmental knowledge, conservation, and the management of a "wilderness" park. Current Anthropology 44:S79-S103. https://doi.org/10.1086/377666

Indigenous Law Research Unit (ILRU). 2010. ILRU analytical framework: environmental issues. ILRU, Victoria, British Columbia, Canada.

Johannes, R. E. 1978. Traditional marine conservation methods in Oceania and their demise. Annual Review of Ecology and Systematics 9:349-364. https://doi.org/10.1146/annurev. es.09.110178.002025

Johannes, R. E. 2002. The renaissance of community-based marine resource management in Oceania. Annual Review of Ecology and Systematics 33:317-340. https://doi.org/10.1146/ annurev.ecolsys.33.010802.150524

Johnson, C. N., A. Balmford, B. W. Brook, J. C. Buettel, M. Galetti, L. Guangchun, and J. M. Wilmshurst. 2017. Biodiversity losses and conservation responses in the Anthropocene. Science 356:270-275. https://doi.org/10.1126/science.aam9317

Jones, R., C. Rigg, and E. Pinkerton. 2017. Strategies for assertion of conservation and local management rights: a Haida Gwaii herring story. Marine Policy 80:154-167. https://doi.org/10.1016/ j.marpol.2016.09.031

Jupiter, S. D., P. J. Cohen, R. Weeks, A. Tawake, and H. Govan. 2014. Locally-managed marine areas: multiple objectives and diverse strategies. Pacific Conservation Biology 20:165-179. https://doi.org/10.1071/PC140165

Kitasoo/Xai'xais First Nation. 2011. Kitasoo/Xai'xais integrated marine use plan. Kitasoo/Xai'xais Integrated Resource Authority, Klemtu, British Columbia, Canada.

Kitasoo/Xai'xais First Nation. 2017. Kitasoo/Xai'xais management plan for Pacific herring. Klemtu, British Columbia, Canada. [online] URL: https://klemtu.com/kitasoo-band/programs-2/comanagement-fisheries/

Lam, M. 1998. Consideration of customary marine tenure system in the establishment of marine protected areas in the South Pacific. Ocean \& Coastal Management 39:97-104. https://doi. org/10.1016/S0964-5691(98)00017-9

Lepofsky, D., and M. Caldwell. 2013. Indigenous marine resource management on the Northwest Coast of North America. Ecological Processes 2:12. https://doi.org/10.1186/2192-1709-2-12

Nursey-Bray, M., and C. Jacobson. 2014. 'Which way?': The contribution of Indigenous marine governance. Australian Journal of Maritime \& Ocean Affairs 6:27-40. https://doi. org/10.1080/18366503.2014.888136

Nursey-Bray, M., and P. Rist. 2009. Co-management and protected area management: achieving effective management of a contested site, lessons from the Great Barrier Reef World Heritage Area (GBRWHA). Marine Policy 33:118-127. https:// doi.org/10.1016/j.marpol.2008.05.002

Office of the High Commissioner for Human Rights. 2008. United Nations declaration on the rights of indigenous peoples: adopted by the General Assembly on 13 September 2007. United Nations, New York, New York, USA.

Ommer, R. E. 2007. Coasts under stress: restructuring and socialecological health. McGill-Queen's University Press, Montreal, Québec, Canada.

Ostrom, E. 1990. Governing the commons: the evolution of institutions for collective action. Cambridge University Press, New York, New York, USA. https://doi.org/10.1017/CBO9780511807763

Ostrom, E. 2009. A general framework for analyzing sustainability of social-ecological systems. Science 325:419-422. https://doi.org/10.1126/science.1172133

Regan, P. 2010. Unsettling the settler within: Indian residential schools, truth telling, and reconciliation in Canada. University of British Columbia Press, Vancouver, British Columbia, Canada.

Richardson, B. J. 2008. The ties that bind: Indigenous peoples and environmental governance. Comparative Research in Law \& Political Economy Research Paper No. 26. Osgoode Hall Law School, York University, Toronto, Ontario, Canada. https://doi. org/10.2139/ssrn.1262781

Schlager, E., and E. Ostrom. 1992. Property-rights regimes and natural resources: a conceptual analysis. Land Economics 68:249-262. https://doi.org/10.2307/3146375

Sievanen, L., R. L. Gruby, and L. M. Campbell. 2013. Fixing marine governance in Fiji? The new scalar narrative of ecosystembased management. Global Environmental Change 23:206-216. https://doi.org/10.1016/j.gloenvcha.2012.10.004

Smith, E. A., and M. Wishnie. 2000. Conservation and subsistence in small-scale societies. Annual Review of Anthropology 29:493-524. https://doi.org/10.1146/annurev.anthro.29.1.493

Stephenson, J., F. Berkes, N. J. Turner, and J. Dick. 2014. Biocultural conservation of marine ecosystems: examples from New Zealand and Canada. Indian Journal of Traditional Knowledge 13:257-265.

Thornton, T., D. Deur, and H. Kitka, Sr. 2015. Cultivation of salmon and other marine resources on the Northwest Coast of North America. Human Ecology 43:189-199. https://doi. org/10.1007/s10745-015-9747-Z

Thornton, T. F., and J. Hebert. 2015. Neoliberal and neocommunal herring fisheries in Southeast Alaska: reframing sustainability in marine ecosystems. Marine Policy 61:366-375. https://doi.org/10.1016/j.marpol.2014.11.015

Trosper, R. L. 2002. Northwest coast indigenous institutions that supported resilience and sustainability. Ecological Economics 41:329-344. https://doi.org/10.1016/S0921-8009(02)00041-1

Trosper, R. L. 2003. Resilience in pre-contact Pacific Northwest social ecological systems. Conservation Ecology 7(3):6. https://doi. org/10.5751/ES-00551-070306 
Trosper, R. L. 2009. Resilience, reciprocity and ecological economics: Northwest Coast sustainability. Routledge, London, UK. https://doi.org/10.4324/9780203881996

Truth and Reconciliation Commission. 2015. Honouring the truth, reconciling for the future: summary of the final report of the Truth and Reconciliation Commission of Canada. Truth and Reconciliation Commission, Ottawa, Ontario, Canada.

Turner, N. J., and F. Berkes. 2006. Coming to understanding: developing conservation through incremental learning in the Pacific Northwest. Human Ecology 34:495-513. https://doi. org/10.1007/s10745-006-9042-0

Veitayaki, J., B. Aalbersberg, A. Tawake, E. Rupeni, and K. Tabunakawai. 2003. Mainstreaming resource conservation: the Fiji Locally Managed Marine Area Network and its influence on national policy development. Australian National University, Canberra, Australian Capital Territory, Australia.

World Commission on Environment and Development. 1987. Our common future. Oxford University Press, Oxford, UK.

Worm, B., E. B. Barbier, N. Beaumont, J. E. Duffy, C. Folke, B. S. Halpern, J. B. C. Jackson, H. K. Lotze, F. Micheli, S. R. Palumbi, E. Sala, K. A. Selkoe, J. J. Stachowicz, and R. Watson. 2006. Impacts of biodiversity loss on ocean ecosystem services. Science 314:787-790. https://doi.org/10.1126/science.1132294

Young, O. R., G. Osherenko, J. Ekstrom, L. B. Crowder, J. Ogden, J. A. Wilson, J. C. Day, F. Douvere, C. N. Ehler, and K. L. McLeod, B. S. Halpren, and R. Peach. 2007. Solving the crisis in ocean governance: place-based management of marine ecosystems. Environment: Science and Policy for Sustainable Development 49:20-32. https://doi.org/10.3200/ENVT.49.4.20-33 